\title{
Effect of Promotion, Price and Distribution Channels on My-Gell Pen Purchase Decisions at PT. Emico Mitra Cemerlang Medan
}

\author{
Fendy $^{1}$, Melinda Siregar², Nelson ${ }^{3}$, Yuni Limtia ${ }^{4}$ \\ ${ }^{1,2,3,4}$ Universitas Prima Indonesia, Indonesia. \\ Corresponding Author: Melinda Siregar
}

DOI: https://doi.org/10.52403/ijrr.20220113

\begin{abstract}
This research is motivated by the decreasing number of consumers of PT. Emico Mitra Cemerlang Medan in the period of 2020. The decline in the number of purchase decisions indicates that purchase decisions products from PT. Emico Mitra Cemerlang Medan by looking at the existing problems, this research is directed to analyze how to increase satisfaction with the support of increasing promotion, price and distribution channels. In this study, the criteria used are regular customers, what is meant by regular customers here are product users who have used PT. Emico Mitra Cemerlang Medan. The number of samples is determined based on the calculation of the Slovin formula with a tolerable error rate of $10 \%$, it will obtain a total sample of 100 people. The data analysis method used in this study is multiple regression. The result of the research shows that promotion, price and distribution channels have a positive and significant effect on purchase decisions. The author's suggestion is to improve purchase decisions by increasing promotion, maintaining purchase decisions and setting price that are more in line with customer abilities. PT. Emico Mitra Cemerlang Medan needs to maintain elements that have been considered good by customers and need to improve things that are still lacking.
\end{abstract}

Keywords: Promotion, Price, Distribution Channels, Purchase Decisions

\section{INTRODUCTION}

PT. Emico Mitra Cemerlang Medan is one of the companies engaged in pen products. At this time the company is experiencing a decline in customer satisfaction which can be seen from sales that are not optimal and also caused by the COVID-19 pandemic. The company during the COVID-19 pandemic did not look optimal and was unable to achieve the sales target expected by the company. This shows a decrease in purchasing decisions which is also a factor in influencing the decline in sales.

The development of purchasing a product can also be seen in the distribution channels carried out by the company. This is because this distribution channel is one of the marketing channels that is often used by companies to market products directly to consumers. If there is no distribution channel, the goods needed by consumers will not be on the market, on the other hand, if the product is easily available, and can be reached by the buyer in a short time, the buyer or consumer will immediately make a decision to buy the product offered.

Based on the description and background above, the researchers are interested in taking the title "Effect of Promotion, Price and Distribution Channels on My-Gell Pen Purchase Decisions at PT. Emico Mitra Cemerlang Medan."

\section{LITERATURE REVIEW}

Promotion is a combination of five main tools consisting of advertising, personal selling, publicity, sales promotion 
and direct marketing. Promotion is one of the variables contained in the marketing mix which has an important role in communicating the existence and value of the product to potential customers. Promotion is one of the variables contained in the marketing mix which has an important role in communicating the existence and value of the product to potential customers.

Price is the amount of value that consumers exchange for the benefits of having or using a product or service whose value is determined by the buyer and seller through a bargaining process, or is set by the seller for one price that is the same for all buyers. Service quality is an effort to fulfill the needs and desires of consumers as well as the accuracy of delivery in balancing consumer expectations.

Distribution channels is a group of interdependent organizations that help make a product or service available for use or consumption by consumers or business users.

\section{RESEARCH METHODS}

This research uses descriptive and quantitative analysis. Descriptive analysis is a type of research that aims to make a systematic, factual and accurate description of the facts and characteristics of the population of a particular area (Pandiangan et al., 2021). Quantitative analysis is a technique that uses mathematical and statistical modeling, measurement, and research to understand behavior. Quantitative analysts represent a given reality in terms of a numerical value (Pandiangan, 2015).

This research was conducted at PT Emico Mitra Cemerlang Medan with the address at Jalan Letda Sujono No. 112 Medan. The research period is December 2020 - November 2021.

According Pandiangan et al. (2018) in Sugiyono, purposive sampling is the selection of samples based on certain characteristics that are considered to have relevance to the characteristics of the population that have been known previously. The number of samples is determined based on the calculation of the slovin formula with a tolerable error rate of $10 \%$, it will obtain a total sample of 100 people.

Library research of reference sources is a form of research that uses library facilities by examining theoretical discussions from various books, articles, and scientific works related to writing (Pandiangan, 2018). The collection technique is the method used by researchers to find out data information by using interviews, documentation studies and using questionnaires.

The data analysis method used in this study is multiple regression. Multiple regression is an extension of simple linear regression. It is used when we want to predict the value of a variable based on the value of two or more other variables (Tobing et al., 2018). The variable we want to predict is called the dependent variable (or sometimes, the outcome, target or criterion variable).

\section{RESULT}

Table 1. Descriptive Statistical Analysis

\begin{tabular}{|l|l|l|l|l|l|}
\hline \multicolumn{7}{|c|}{ Descriptive Statistics } \\
\hline & $\mathbf{N}$ & Minimum & Maximum & Mean & Std. Deviation \\
\hline Promotion & 37 & 33.00 & 49.00 & 43.4595 & 3.20238 \\
\hline Price & 37 & 25.00 & 39.00 & 32.3514 & 3.54508 \\
\hline Distribution Channels & 37 & 25.00 & 40.00 & 34.3514 & 3.47384 \\
\hline Purchase Decisions & 37 & 37.00 & 50.00 & 43.5135 & 3.33018 \\
\hline Valid N (listwise) & 37 & \multicolumn{7}{|l|}{ Source: Research Results (2021) } \\
\hline
\end{tabular}

Descriptive statistics relate to how data can be described or described or can also be inferred. Table 1 shows that the measurement ratio of the promotion with an average value of 43.45 , while the standard deviation is 3.20238. In the price, the 
Fendy, Melinda Siregar et.al. Effect of promotion, price and distribution channels on my-gell pen purchase decisions at PT. Emico Mitra Cemerlang Medan.

average value is 32.35 , while the standard deviation is 3.54508. In the distribution channels with an average value of 34.35 , the standard deviation is 3.47384. In the purchase decisions with an average value of 43.51, the standard deviation is 3.33018 .

Table 2. One Sample Kolgomorov Smirnov Test One-Sample Kolmogorov-Smirnov Test

\begin{tabular}{|l|l|r|}
\hline \multicolumn{2}{|c|}{ One-Sample Kolmogorov-Smirnov Test } \\
\hline \multicolumn{2}{|c|}{} & $\begin{array}{l}\text { Unstandardized } \\
\text { Residual }\end{array}$ \\
\hline $\mathrm{N}$ & Mean & .0000000 \\
\hline Normal & & 37 \\
Parameters ${ }^{\mathrm{a}, \mathrm{b}}$ & Std. Deviation & .95619830 \\
\hline Most Extreme & Absolute & .067 \\
\cline { 2 - 3 } Differences & Positive & .067 \\
\cline { 2 - 3 } & Negative & -.046 \\
\hline Kolmogorov- Smirnov Z & .406 \\
\hline \multicolumn{2}{|l|}{ Asymp. Sig. (2-tailed) } & .997 \\
\hline \multicolumn{2}{|c|}{ Source: Research Results (2021) } \\
\hline
\end{tabular}

Based on Table 2 above, it can be seen that the Sig value is $0.997>0.05$, so it can be concluded that the data is normally distributed.

Table 3. Multicollinearity Test

\begin{tabular}{|l|l|l|l|}
\hline \multicolumn{3}{|c|}{ Coefficients $^{\mathbf{a}}$} \\
\hline \multicolumn{3}{|c|}{ Model } & \multicolumn{2}{|c|}{ Collinearity Statistics } \\
\cline { 2 - 4 } \multicolumn{2}{|c|}{1} & Tolerance & VIF \\
\cline { 2 - 4 } & Promotion & .716 & 1.396 \\
\cline { 2 - 4 } & Price & .689 & 1.451 \\
\cline { 2 - 4 } & Distribution Channels & .524 & 1.909 \\
\hline \multicolumn{3}{|c|}{ a. Dependent Variable: Purchase Decisions } \\
\hline
\end{tabular}

From the results of the variable test in Table 3 above, it can be seen that the tolerance value of each independent variable is $\quad$ promotion $=0.716$, $\quad$ price $=0.689$, distribution channels $=0.54$ While the VIF value of each independent variable is promotion $=1.396$, price $=1.451$, distribution channel $=1.909$ so that the related data is independent of multicollinearity.

Table 4. Glejser Test

\begin{tabular}{|c|c|c|c|c|c|c|}
\hline \multicolumn{7}{|c|}{ Coefficients $^{\mathrm{a}}$} \\
\hline \multirow{2}{*}{\multicolumn{2}{|c|}{ Model }} & \multicolumn{2}{|c|}{ Unstandardized Coefficients } & \multirow{2}{*}{$\frac{\text { Standardized Coefficients }}{\text { Beta }}$} & \multirow[t]{2}{*}{$\mathbf{t}$} & \multirow[t]{2}{*}{ Sig. } \\
\hline & & $\mathrm{B}$ & Std. Error & & & \\
\hline \multirow[t]{4}{*}{1} & (Constant) & 6.522 & 3.396 & & 1.920 & .064 \\
\hline & Promotion & -.135 & .068 & -.367 & -1.977 & .057 \\
\hline & Price & .078 & .063 & 234 & 1237 & .225 \\
\hline & Distribution Channels & -.019 & .049 & -.049 & -.382 & .704 \\
\hline
\end{tabular}

Source: Research Results (2021)

Based on Table 4, it can be seen that the three variables have an asym.sig value above 0.05, which can be seen that promotion with a value of 0.057 , price with a value of 0.225 , Distribution channel with a value of 0.704 so that the data does not occur heteroscedasticity symptoms.

Table 5. Results of Multiple Linear Regression Analysis

\begin{tabular}{|c|c|c|c|c|c|c|}
\hline \multirow{2}{*}{\multicolumn{2}{|c|}{ Model }} & \multicolumn{2}{|c|}{ Unstandardized Coefficients } & \multirow{2}{*}{$\begin{array}{c}\text { Standardized Coefficients } \\
\text { Beta }\end{array}$} & \multirow[t]{2}{*}{$\mathbf{t}$} & \multirow[t]{2}{*}{ Sig. } \\
\hline & & $\mathbf{B}$ & Std. Error & & & \\
\hline \multirow[t]{4}{*}{1} & (Constant) & .778 & 2.145 & & .993 & .324 \\
\hline & Promotion & .275 & .128 & .264 & 2.153 & .039 \\
\hline & Price & .354 & .118 & .356 & 3.450 & .005 \\
\hline & Distribution Channels & .313 & .138 & .327 & 4.043 & .030 \\
\hline
\end{tabular}

Source: Research Results (2021)

Based on Table 5 above, the e $=0.10$

regression model is obtained, it can be seen: Thus, the regression model is $\begin{array}{ll}\text { a } & =0.778 \\ \text { b1 } & =0.275 \\ \text { b2 } & =0.354 \\ \text { b3 } & =0.313\end{array}$ obtained, namely employee performance: $0.778+0.275$ Promotion +0.354 Price + 0.313 Distribution Channels.

Table 6. Results of the Coefficient of Determination

\begin{tabular}{|l|c|c|c|c|}
\hline \multicolumn{5}{|c|}{ Model Summary $^{\mathbf{b}}$} \\
\hline Model & R & R Square & Adjusted R Square & Std. Error of the Estimate \\
\hline 1 & $.809^{\text {a }}$ & .655 & .612 & 2.07486 \\
\hline \multicolumn{5}{|c}{ Predictors (Constant): Promotion, Price, Distribution Channels } \\
Dependent Variable : Purchase Decisions \\
Source: Research Results (2021)
\end{tabular}


Fendy, Melinda Siregar et.al. Effect of promotion, price and distribution channels on my-gell pen purchase decisions at PT. Emico Mitra Cemerlang Medan.

Based on Table 6 above, it can be concluded that:

a. $\mathrm{R}=0.809$ indicates a high correlation between the variables promotion, price, distribution channels, purchase decisions.

b. The R Square coefficient value is $65.5 \%$ which shows that the purchase decisions variables (Y) can be explained by the promotion, price, distribution channels variables while the remaining $35.5 \%$ is influenced by other independent variables that cannot be explained in this study.

Table 7. Simultaneous Test (F Test)

\begin{tabular}{|c|c|c|c|c|c|c|}
\hline \multicolumn{7}{|c|}{ ANOVA $^{\mathrm{a}}$} \\
\hline \multicolumn{2}{|c|}{ Model } & Sum of Squares & df & Mean Square & $\mathbf{F}$ & Sig \\
\hline \multirow[t]{3}{*}{1} & Regression & 261.482 & 4 & 65.370 & 15.185 & $.000^{\mathrm{a}}$ \\
\hline & Residual & 137.762 & 32 & 4.305 & & \\
\hline & Total & 399.243 & 36 & & & \\
\hline \multicolumn{7}{|c|}{ a. Predictors: (Constant), Promotion, Price, Distribution Channels } \\
\hline \multicolumn{7}{|c|}{ b. Dependent Variable: Purchase Decisions } \\
\hline
\end{tabular}

From Table 7 above, it can be seen that Fcount is 15.185 more than Ftable, which is 2.67 with sig $0.000<0.05$. Related results show that together $\mathrm{H} 1$ is accepted and $\mathrm{HO}$ is rejected. This means that promotion, price, distribution channels are immediate and significant to purchase decisions at PT. Emico Mitra Cemerlang Medan.

Table 8. Partial Test (t Test)

\begin{tabular}{|c|c|c|c|c|c|c|}
\hline \multicolumn{7}{|c|}{ Coefficients $^{\mathrm{a}}$} \\
\hline \multirow{2}{*}{\multicolumn{2}{|c|}{ Model }} & \multicolumn{2}{|c|}{ Unstandardized Coefficients } & \multirow{2}{*}{$\begin{array}{c}\text { Standardized Coefficients } \\
\text { Beta } \\
\end{array}$} & \multirow[t]{2}{*}{$\mathbf{t}$} & \multirow[t]{2}{*}{ Sig. } \\
\hline & & B & Std. Error & & & \\
\hline \multirow[t]{4}{*}{1} & (Constant) & .778 & 2.145 & & .993 & .324 \\
\hline & Promotion & .275 & .128 & .264 & 2.153 & .039 \\
\hline & Price & .354 & .118 & .356 & 3.450 & .005 \\
\hline & Distribution Channels & .313 & .138 & .327 & 4.043 & .030 \\
\hline
\end{tabular}

Source: Research Results (2021)

Based on Table 8 above shows that:

1. The t test of the promotion has a tcount of $2.153>2.037$. Significance of 0.039 is less than 0.05 , meaning that the promotion has a positive and significant effect on purchase decisions.

2. The $t$ test of the price has a tcount of $3.450>2.037$. Significance of 0.005 is less than 0.05 , meaning that the price has a positive and significant effect on purchase decisions.

3. The $t$ test of the distribution channels has a tcount of $4.043>2.037$. Significance of 0.030 is less than 0.05 , meaning that the distribution channels have a positive and significant effect on purchase decisions.

\section{CONCLUSION AND SUGGESTION Conclusion}

Based on the results and discussion, it can be concluded that the research is:

1. Partially shows if the promotion has a positive and significant effect on purchase decisions at PT. Emico Mitra Cemerlang Medan.

2. Partially shows if the price has a positive and significant effect on the purchase decision at PT. Emico Mitra Cemerlang Medan.

3. Partially distribution channels have a significant positive effect on purchase decisions at PT. Emico Mitra Cemerlang Medan.

4. Promotion, price and distribution channels have a positive and significant effect on purchase decisions. 
Fendy, Melinda Siregar et.al. Effect of promotion, price and distribution channels on my-gell pen purchase decisions at PT. Emico Mitra Cemerlang Medan.

\section{Suggestion}

In this study, the suggestions for the authors convey are as follows:

1. Researchers suggest to companies to prioritize promotions that are beneficial for the company because promotions are very attractive in market share.

2. The researcher's suggestion to the company is to continue to do price management, so that the price given is commensurate with the quality given in the pen.

3. The researcher's suggestion to the company is to pay more attention to the distribution channel side so that there is no delay in the entry of goods, so as not to cause customer/user disappointment.

\section{Acknowledgement: None}

\section{Conflict of Interest: None}

\section{Source of Funding: None}

\section{REFERENCES}

1. Hasan, Ali. (2013). Marketing dan KasusKasus Pilihan. Jakarta: PT Indeks.

2. Iranita, A., \& Suprihartini, L. (2017). Pengaruh Kualitas Produk, Saluran Distribusi dan Keputusan Pembelian Terhadap Hasil Penjualan Karet Alam Sumatera Barat.

3. Dewi, I. T., \& Hasibuan, M. I. (2016). Pengaruh Pengalaman Pelanggan (Customer Experience) Terhadap Keputusan Pembelian pada Rumah Makan Kuliner Jawa Rantauprapat. ECOBISMA Jurnal Ekonomi, Bisnis dan Manajemen.

4. Ghozali, Iman. (2011). Alpikasi Analisis Multivatiate dengan Program SPSS. Semarang: Badan Penerbit Universitas diponegoro.

5. Gulla, R., Oroh, S. G., \& Roring, F. (2015). Analisis Harga, Promosi, dan Saluran Distribusi terhadap Kepuasan Konsumen pada Hotel Manado Grace Inn. Jurnal EMBA: Jurnal Riset Ekonomi, Manajemen, Bisnis dan Akuntansi.

6. Mulyono, S. H., \& Djatmiko, T. (2018). Pengaruh Customer Experience Terhadap Customer Satisfaction di Tokopedia. eProceedings of Management.
7. Pandiangan, Saut Maruli Tua. (2015). Analisis Lama Mencari Kerja Bagi Tenaga Kerja Terdidik di Kota Medan. Skripsi. Medan: Fakultas Ekonomi dan Bisnis, Program Studi Ekonomi Pembangunan, Universitas Sumatera Utara. https://www.academia.edu/52494724/Analis is_Lama_Mencari_Kerja_Bagi_Tenaga_Ker ja_Terdidik_di_Kota_Medan.

8. Pandiangan, Saut Maruli Tua. (2018). Analisis Faktor-faktor yang Mempengaruhi Penawaran Tenaga Kerja Lanjut Usia di Kota Medan. Tesis. Medan: Fakultas Ekonomi dan Bisnis, Program Studi Ilmu Ekonomi, Universitas Sumatera Utara. http://repositori.usu.ac.id/bitstream/handle/1 23456789/10033/167018013.pdf?sequence= $1 \&$ is Allowed $=\mathrm{y}$.

9. Pandiangan, Saut Maruli Tua, Rujiman, Rahmanta, Tanjung, Indra I., Darus, Muhammad Dhio, \& Ismawan, Agus. (2018). An Analysis on the Factors which Influence Offering the Elderly as Workers in Medan. IOSR Journal of Humanities and Social Science (IOSR-JHSS), 23(10), 76-79. DOI: 10.9790/0837-2310087679.

10. Pandiangan, Saut Maruli Tua, Resmawa, Ira Ningrum, Simanjuntak, Owen De Pinto, Sitompul, Pretty Naomi, \& Jefri, Riny. (2021). Effect of E-Satisfaction on Repurchase Intention in Shopee User Students. Budapest International Research and Critics Institute-Journal, 4(4), 77857791.

DOI: https://doi.org/10.33258/birci.v4i4.2697.

11. Salim, K. F., Catherine, C., \& Andreani, F. (2015). Pengaruh Customer Experience dan Kepercayaan Terhadap Keputusan Konsumen di TX Travel Klampis. Jurnal Hospitality dan Manajemen Jasa.

12. Sangadji, E.M., \& Sopiah. (2013). Perilaku Konsumen Pendekatan Praktis. Yogyakarta: CV Andi Offset.

13. Sugiono. (2016). Metode Penelitian Kuantitatif, Kualitatif dan R\&D. Bandung: PT Alfabet.

14. Tjiptono, F. (2012). Service Management: Mewujudkan Layanan Prima. Edisi II. Yogyakarta: Andi.

15. Tjiptono, F., \& Chandra, G. (2016). Service, Quality dan Satisfaction. Edisi 4. Yogyakarta: Andi Offset.

16. Tobing, Murniati, Afifuddin, Sya'ad, Rahmanta, Huber, Sandra Rouli, Pandiangan, Saut Maruli Tua, \& Muda, 
Fendy, Melinda Siregar et.al. Effect of promotion, price and distribution channels on my-gell pen purchase decisions at PT. Emico Mitra Cemerlang Medan.

Iskandar. (2018). An Analysis on the Factors Which Influence the Earnings of Micro and Small Business: Case at Blacksmith Metal Industry. Academic Journal of Economic Studies, 5(1), 17-23. https://www.ceeol.com/search/articledetail id $=754945$.
How to cite this article: Fendy, Melinda Siregar, Nelson et.al. Effect of promotion, price and distribution channels on my-gell pen purchase decisions at PT. Emico Mitra Cemerlang Medan. International Journal of Research and Review. 2022; 9(1): 83-88. DOI: https://doi.org/ 10.52403/ijrr.20220113 